\title{
CONCEPTUAL FRAMEWORK OF GREEN-BUILDING ADOPTION AMONG CONSTRUCTION COMPANIES IN SAUDI ARABIA: THE EFFECT OF PROACTIVE ENTREPRENEURIAL BEHAVIOR, GREEN PRODUCT INNOVATION, AND GOVERNMENT SUPPORT
}

\author{
Asem Alkahtani $1^{1, *}$ and Norfarah Nordin ${ }^{1}$ \\ ${ }^{1}$ Graduate School of Business, Universiti Sains Malaysia
}

ABSTRACT - Saudi Arabia is facing the rising of the global population and high resource use. The country needs to inculcate the adoption of sustainable practices, i.e. green building practices. However, adopting green building practices for a sustainable future requires fundamental changes in the way contractors build houses. This paper endeavours to conceptualize the elements that contribute to the adoption of green building among the contraction companies in Riyadh. Literature reviews and government document reviews are used for the conceptualization of the framework. Based on the resource-based view theory, the factors are conceptualized with small and mediumsized enterprise contractors as the subject of focus. This paper proposes that green builders or the construction companies' internal resources, i.e. proactive entrepreneurial behaviour, are hypothesized to influence green building adoption. However, risk-taking and green product innovation are proposed to mediate the relationships. These factors are moderated by Saudi Arabian government support, financial and non-financial. By addressing these factors regarding green building practices, Saudi Arabia would be able to achieve sustainable development in the housing of its citizens.

\author{
ARTICLE HISTORY \\ Received: $13-8-2020$ \\ Accepted: 1-12-2020 \\ KEYWORDS \\ Proactive Behavior \\ Innovation \\ Financial and Non- \\ Financial Government \\ Support \\ Green-Building \\ Sustainability \\ Riyadh
}

\section{INTRODUCTION}

According to the Saudi Arabia governmental vision 2030, the main feature of the vision is to shift Saudi Arabia's economy from oil dependency to other sectors and make a clean and green environment (Alshuwaikhat, \& Mohammed, 2017). Saudi Arabia's economy is mostly dependent on the oil sector (Bahidrah, \& Korkmaz, 2017) because it discovered oil nine decades ago, and the Saudi government has become the top oil producer and exporter in the whole world ever since (Hagihara, 2013). For the last three decades, Saudi Arabia's economy grew multiple times through natural gas and oil (Ong, Mahlia, \& Masjuki, 2011). It is also considered to be the largest consumer of petroleum in the Middle East (EIA, 2013) following that the energy sector is all dependent on fossil fuels (Rahman \& Khondaker, 2012). Thus, the country is facing a distinctive problem with greenhouse gas emissions (Mosly, 2015). Saudi Arabia has become the largest polluter on the planet (Mosly, \& Makki, 2018), therefore, they need to reduce the $\mathrm{CO}_{2}$ emissions. It is estimated that if KSA continues to use the local oil consumption at the same rate, at the end of 2030, the kingdom should have consumed all of its domestic oil production (Yamada, Vision 2030). Hence, for the oil replacement, the Saudi government presented the vision 2030 to shift the economic dependency from oil towards the other sectors. This is due to the KSA government's inability to sustain for the long-term through the oil sector. In relation to this matter, the government is planning to adopt an innovative policy for getting a clean and green environment.

The regular construction sector practices consume a large number of resources, which badly affect the environment (Alnaser, \& Alnaser, 2011). Therefore, in order to get a green and clean Saudi environment, the construction sector is considered as the easiest way to shift from regular construction towards green projects. This is based on the fact that the building industry has one of the highest adverse impacts on the natural environment (Rahardjati, Khamidi, \& Idrus, 2011). The importance of climate change and global warming are putting increasing pressure on all nations to implement strategic methods in enhancing the sustainability of the built environment while protecting their natural resources (Alyami, Rezgui, \& Kwan, 2013). Hence, the strategic importance of environmental and sustainable assessment schemes was crafted (Crawley, \& Aho, 1999). In KSA, there are more than 31 million people with a growth rate of 5\% per year (Amran, et al., 2020). Almost 70\% of the residents are under the age of 30, and annual new houses are projected to increase to 2.32 million units by 2020 (Alrashed, \& Asif, 2015). This large number of regular constructions is the main culprit and they significantly affect the climate due to the use of regular materials which can impact humans and the environment (Tushar, et al., 2018). The public and government are demanding sustainability due to worldwide environmental disasters that resulted from pollution and manufacturing activities. This can be achieved through the encouragement and adoption of a series of measures, including lean construction, green buildings, and better waste management. 
Saudi Arabia is one of the richest countries, but the green project numbers are very low as compared to other Asian countries. It seems that many obstacles exist which decelerate the development of a green economy in Saudi Arabia. Climate change is leading to wide-ranging challenges because Saudi Arabia is ranked $60^{\text {th }}$ in the climate change performance index in 2019 (CCPI, 2020), which is the second last position in the index (Asif, 2012; Alrashed \& Asif, 2014). In order to find a solution, it is crucial to understand these challenges (Chan et al., 2009). Major barriers include political and structural barriers, economic and financial barriers, behavioral and cultural barriers, information barriers, and skill barriers (Darko et al., 2013; Darko and Chan, 2016).

However, these barriers have become the main obstacles to sustaining green projects in Suadi Arabia. Several researchers tried to find out the solution to these obstacles in different contexts (Banani, et al., 2016; Alyami, Rezgui, \& Kwan, 2015; Yadegaridehkordi et al., 2020), still, they were not successful in their mission. Hence, the current study is conducted to examine the role of green building technological innovation and government support in pushing the construction companies towards green building adoption. It was suggested that green technological innovation and adoption can help to easily install green projects. Pertaining to this matter, the government is needed to launch financial support (loans, incentives, and discounts) and create awareness among the construction companies, top managers, through workshops or seminars.

Green construction projects play a significant role in economic growth. In green building practices, construction aims to reduce natural resource consumption through green technologies such as green roofs, solar energy, and precast concrete as these green concretes are used for the development of green projects. In the Gulf Cooperation Council (GCC) region, the building sector is experiencing a quick expansion due to factors such as economic growth, burgeoning populations, and modernization. Therefore, the current study's main objective is to identify future customers' demands and make every investment decision very confidentially, while the government needs to create awareness among the contractors about governmental plans. The recent change in interest by policymakers encourages the development of a green economy, with a specific focus on the attempts of the government of Saudi Arabia to create a platform in shifting the construction sector through green building techniques (Albanawi, 2015; Greenwood, 2012). The global UN survey found that the regular construction sector is the largest contributor to GHG emissions (UNEP, 2011).

The next section provides a literature review that describes probable factors that contribute to green building adoption. This is followed by a review of the methodology. The final section provides the proposed conceptual framework for green building adoption for Saudi Arabian construction SME contractors.

\section{LITERATURE REVIEW}

Green building plays a pivotal and effective role in improving energy efficiency (Vyas \& Jha, 2017). Researchers study the environmental, health, and social issues of an architecture's life cycle (Liu, Guo, \& Hu, 2014). Green building technologies include solar systems and green roofs, and the implementation of green technologies in the construction project is crucial (Chan, Darko, \& Ameyaw, 2017). Several green technologies have been integrated into green construction projects, such as green roofs, solar energy, and precast concrete. The green buildings projects are needed to install such kind of technologies, which are the combination of green technologies and green clay because it helps to minimize the effect on human lives and the environment (Chan, et al., 2017). Koebel et al., (2015) suggested that green building technologies, such as high-efficiency windows, green roofs, and solar shading devices, significantly reduce environmental pollution.

Green building adoption has specific criteria for buildings to be recognized as green projects. This study followed the Saudi Arabian government's rules and regulations. For the ranking of green construction projects, Saudi Arabia developed a rating system (Mustadam, 2019), under the supervision of the Ministry of Housing developed for the Saudi Arabian market. In addition, this rating system was the inspiration for Saudi Vision 2030 objectives.

Mostadam has three main objectives. He specifically targeted the residential, communities, and commercial buildings. He also explained different categories which (1) site sustainability, (2) sufficient Energy and Water Use, (3) Transportation and Connectivity, (4) Region and Culture, (5) Health and Comfort, (6) Education and Innovation, (7) Materials and Waste, and (8) Policies and Maintenance.

\section{METHODOLOGY}

This study aims to check the mediating effect of green product innovation and risk-taking between proactive entrepreneurial behavior and green building adoption while the government supports the relationship. In order to achieve this objective, the quantitative nature study will be conducted, and the data will be collected from the contractor SME's top management because they have more information about decision making. There are a total of more than 10,000 contractor companies operationalized in Riyadh. This study will be to collect data from 364 contractor companies. For data collection, random sampling techniques will be used and the data will be collected through structured questionnaires. For descriptive statistics, SPSS 24 will be used along with Smart PLS for structured and measurement models. 


\section{FINDINGS AND DISCUSSION}

\section{RESOURCE-BASED VIEW THEORY}

This study was conducted to respond to the external environment and to modify the existing resources according to the market demand. The firm's innovation capability can help to respond to external market changes and their conditions to gain higher profits. Innovativeness might require new ways of operating, technological support, management skills, and knowledge to create values (Day, 2014; Kozlenkova et al., 2014).

Drawing on the past literature and resource-based view (RBV) theory, this study's research model included a firm's innovativeness as a core driver for higher performance (Lii \& Kuo, 2016; Cucculelli \& Bettinelli, 2015). Proactiveness works as essential behavior, assists firms to enter into the market ahead of competitors, and seizes early profits (Devis et al., 2010; Lester et al., 2008; Wiklund \& Shepherd, 2005). In addition, it should be mentioned that entrepreneurial activities and green product innovation are the internal resources for firms, which help to enhance green building performance. As firms aim to enter into the market, differentiating products or lowering product costs is required, and the firms must take a risk. RBV theory embraces these activities concerning the achievement of higher performance.

Therefore, the framework of this study was conceptualized based on RBV theory, which provides the underlying foundation for the model conceptualization, where internal and external resources are hypothesized as important factors to enhance the green building adoption of construction SMEs' performance. Moreover, RBV theory states that firms' superior performances can be the result of the utilization of the firms' unique resources and external assistance, such as assistance for the government (Barney, 1991).

\section{Proactive entrepreneurial behavior and construction green building adoption}

Proactive entrepreneurial behavior refers to the strategic decision of top management in following new opportunities and taking initiative, which is a salient characteristic of entrepreneurship (Xie, Huo, \& Zou, (2019). According to RBV theory, postulating a firm's characteristics level behavior is a core resource for sustainable competitive performance (Barney 1991). In this study, the proactive entrepreneurial behavior works as a deeply-rooted value that directly makes a significant contribution to achieve excellent performance (Li, Jayaraman, Paulraj, \& Shang, 2016; Ong, Lee, Teh, \& Magsi, 2019), and these salient characteristics are considered as a core resource for competitive advantage (Lumpkin \& Dess, 1996; Zhou et al., 2005). Several researchers defined the concept of proactive entrepreneurial behavior as the tendency of the firms to study the future market demands in creating a business environment (Li, Jayaraman, Paulraj, \& Shang, 2016; Strauss, Parker, \& O'Shea, 2017).

In addition, the firms which put a strong concentration on the collection of information and knowledge according to the customer demand can help to sustain competitive advantage (Covin et al., 2000; Mueller et al., 2012). Having pioneers' ability for firms to reproduce the motivation of being highly opportunistic is important (Lumpkin \& Dess, 1996; Simon et al., 2002; Song et al., 2000). In contrast, having a highly proactive ability of the companies in investing resources for achieving the final objective is crucial (Dangelico, Pujari, \& Pontrandolfo, 2017; Chang, 2018). Hence, in the current study, construction companies' exposure can significantly support in achieving green building adoption. Top managements' exposure to governmental policies and customer demands can help the organization to sustain competitive performance. Furthermore, when highly proactive companies continuously engage in green building adoption, their nature to use new technologies increases (Liu, Ko, Ngugi, \& Takeda, 2017; Neneh, 2019). On the basis of previous literature, this study posited that there is a positive connection between PEB and green building adoption.

$$
H_{1} \text {. Proactive entrepreneurial behavior has a positive and significant effect on green building adoption. }
$$

\section{Proactive Entrepreneurial behavior and green product innovation}

Proactive entrepreneurial behavior is defined as bringing initiatives in the product through the existing resources as per the market demand in reducing labor costs, in order to sustain external opportunities and competitive advantage (Chen, Chang, \& Wu, 2012). In addition, Covin and Slevin (1989) explained that a firm that has a pioneer (proactive) ability can lead competitors in the market. In the current era, a firm can easily gain or explore knowledge and information from the external market due to the social media war. A firm that has a high level of pioneers' ability usually has a high motivation towards opportunity recognition (Gladwin, Kennelly, \& Krause, 1995).

Moreover, PEB usually comes with advanced strategies that provide companies with more opportunities to sustain competitive advantages (Hart, 1995). The organization which has symmetric information about the future market and the governmental planning can utilize the existing resources and modify the product using the collected information. In regards to PEBs, companies are in critical condition as they are assumed to commit to investing in innovation, organizational systems, products, and services for continuous recycling (Moss, Neubaum, \& Meyskens, 2015). The companies that use PEBs also take initiative in green product innovation. Therefore, based on previous literature, this study postulated that proactive entrepreneurial behavior has a positive effect on green product innovation.

H2. Proactive entrepreneurial behavior has a significant effect on green product innovativeness.

\section{Green product Innovation and Risk-taking as mediators}

This study proposed that green product innovation functions as a mediator between PEB and green building adoption. Green innovation includes the development of green products and processes that adjust existing product designs to reduce any negative effect on the environment throughout any stage of a product's life cycle (Chiou et al. 2011). Green product innovation indicates a firm's ability to improve existing processes and develop new processes that create green innovation 
and high performance. Additionally, green innovation is highly related to energy savings, pollution prevention, waste recycling, or reduced toxicity in innovation processes (Chen et al. 2006; Chen, 2008).

The relationship among the latest contracts was built through resource-based view theory. RBV suggests that an organization's internal and external resources are the main source of sustainable competitive performance (Murray et al., 2011; Zhou et al., 2008). The organization's pioneers' ability can get the external market demand, and explore all these external knowledge as the firm's proactive capability enhances the performance (Teece et al., 1997). In addition, Kreiser et al. (2013) suggested that a firm's resource capability framework is the best representation of a pioneer's ability. This study proposed green product innovation to be a type of organizational capability that reconciles between proactive entrepreneurial behavior and construction green building adoption. This perspective was built in previous research that highlighted the important contribution of innovation capability to a GBA program's success (Ngo \& O'Cass, 2012; Verhees \& Meulenberg, 2004) and the importance of PEB in driving the engagement of innovation activities (e.g. Covin et al., 2000; Kreiser et al., 2013).

Hence, the firm's top management ability to create the environment of exploring the external environment, and collecting the knowledge and information according to the future market demand, can easily enhance the performance (Amit \& Schoemaker, 1993; Murray et al., 2011). According to the prior discussion, Murray et al. (2011) suggested that proactive entrepreneurial behavior is also an internal organizational resource, which supports in achieving the final target. However, Strauss, Parker, and O'Shea (2017) suggested that a large number of asymmetric information in the open market are considered as the main source of failure. Therefore, Xie, Huo, and Zou (2019) explained that green product innovation is the best source of sustainable competitive performance. A firm that has symmetric information about future market demands and green product innovation capability can easily adapt to the green building compared to the competitor.

In addition, a firm that has high-level pioneers capability can push towards motivation, as top managers have symmetric information about the government plan and customer demands (Xie, Huo, \& Zou, 2019). Utilization of these experience and knowledge can build a new product or service which is different from the competitors (Ryszko, 2016). Hence, on the basis of the previous literature, it is suggested that a large number of pioneers' capabilities can enhance the firm's innovation capability (Li, Jayaraman, Paulraj, \& Shang, 2016; Ong, Lee, Teh, \& Magsi, 2019). Therefore, in the current study, contract companies that have a proactive capability can positively impact the contract companies' innovation capability. Furthermore, innovation capability can help to sustain competitive performance in the organization. Developing products or services using new ideas is the best source for the firm. Previous literature also suggested that a firm that has the ability to develop a new product can easily gain a competitive advantage. This study employed green product innovation as a mediator in the relationship between proactive entrepreneurial behavior and green building adoption. Various studies suggested green product innovation to be considered as a mediator (Xie, Huo, \& Zou, 2019; Dangelico, Pujari, \& Pontrandolfo, 2017; Chang, 2018). This research also suggested that green product innovation can play a mediation role in the endogenous variables. Hence, on the basis of the previous literature, we posited that green product innovation mediates the relationship between proactive entrepreneurial behavior and green product innovation.

H3. Green product innovation significantly mediates the connection between proactive entrepreneurial behavior and green building adoption.

H4. Risk-taking significantly mediates the connection between proactive entrepreneurial behavior and green building adoption.

\section{Government Financial Support and Green product innovation}

Governmental support can, directly and indirectly, enhance firms' innovation performance (Cano-Kollmann et al., 2017; Holl \& Rama, 2012; Kang \& Park, 2012). Organizations that have strong governmental financial and non-financial support can buy new technologies and launch new projects (Caloffiet al., 2015). Several studies have been conducted (Thongsri, \& Chang, 2019; Zhang, \& Guan, 2018) in which the findings suggested that governmental support such as R $\& \mathrm{D}$, grants, and incentives can promote the firm's technological capability. In addition, a lot of organizational support in terms of finance, loans, incentives, and R \& D can help the top management in taking confident decisions and investing in risky projects (Brandao-Marques, Correa, \& Sapriza, 2020; Uddin, 2016). Awareness among top managers and employees regarding innovation can also promote firms' innovation performance (Holl and Rama, 2012). Therefore, the government's financial support strengthens the relationship between construction green product innovation and risktaking (Jugend, Jabbour, Scaliza, Rocha, Junior, Latan, \& Salgado, 2018). This study proposed the following hypothesis:

\section{H5. Government financial support significantly impacts green product innovation. \\ H6. Government financial support significantly impacts risk-taking.}

\section{Government financial support as Moderator}

Applying this logic, a previous study by Boso et al. (2012) argued that it is improbable for less proactive behavior of employers to assign many resources, such as government support, to support innovation-related activities. This is due to the fact that being proactive can help introduce new products to seize new opportunities. Therefore, government incentives are needed in the market as humans, plantation, and environment cleanliness become a priority (Wong, Wong, \& BoonItt, 2015). Covin and Slevin (1989) highlighted that a company with proactive strategies introduces new products to 
become a leading competitor in the turbulent market. The proactive strategic behavior of employers can also help to innovate new products as per the future demand (Gladwin, Kennelly, \& Krause, 1995). While the relationship between proactive entrepreneurial behavior and green product innovation may not be linear, there is an inconsistency found between proactive entrepreneurial behavior and green product innovation. According to Baren and Canney (1986), if there is any inconsistency between the two variables, putting any third external factor can strengthen or weaken the relationship between these two variables. Some authors debated that this influence is moderate (e.g., Dess, Lumpkin, \& Covin, 1997). Hence, many researchers suggested government support (Mitrega, Forkmann, Zaefarian, \& Henneberg, 2017; Anwar \& Shah, 2018) as a moderator for organizational strategic decisions and firm performance. Government support was used as a moderator in previous studies, such as Bamgbade, et al. (2018), who used government support as a moderator in the relationship between organizational culture and firm performance in the Malaysian context. Quan, Wu, Li, and Ying (2018) as well as Khan (2019), used government support as a moderator between sustainable development and employee engagement in China.

This study used government support as a moderator between proactive entrepreneurial behavior and green product innovation because according to Zerbinati and Souitaris (2005) and Michael and Pierce (2009), policies on government subsidies have been detected to have a clear influence on the processes and results of both new and established construction firms. Government support refers to the support rendered by the authority to encourage the spread of sustainable construction within the construction industry. It is well recognized that the government and its agencies are the key players in the promotion of sustainable construction. Government is a well-established factor that exerts a noteworthy influence on green standards (Manning et al., 2012; Khan \& Ghufran, 2018), environmental protection (Kumar, 2013), and social well-being of tenants and construction workers (Azar \& Menassa, 2012; Hua et al., 2014; Kien \& Ofori 2002; Nguyen \& Aiello 2013; Spiegel \& Meadows 2010) For instance, research proposed that governments and construction employers are committing to new green product innovation standards as an important obligation to the society (Rodriguez Lopez \& Fernandez Sanchez, 2011). It has also been noted that the concern of construction sustainability belongs to the government, its agencies, and the construction companies (Shi et al., 2013). Hence, based on past research, this study postulated that government support strengthens the relationship between proactive entrepreneurial behavior and green product innovation.

H7. Government support significantly moderates the relationship between proactive entrepreneurial behavior and green product innovation.

H8. Government support significantly moderates the relationship between proactive entrepreneurial behavior and risk-taking.

Figure 1 shows the factors highlighted as the predictors of green building adoption, addressing these predictors would help the process of green building adoption in Saudi Arabia.

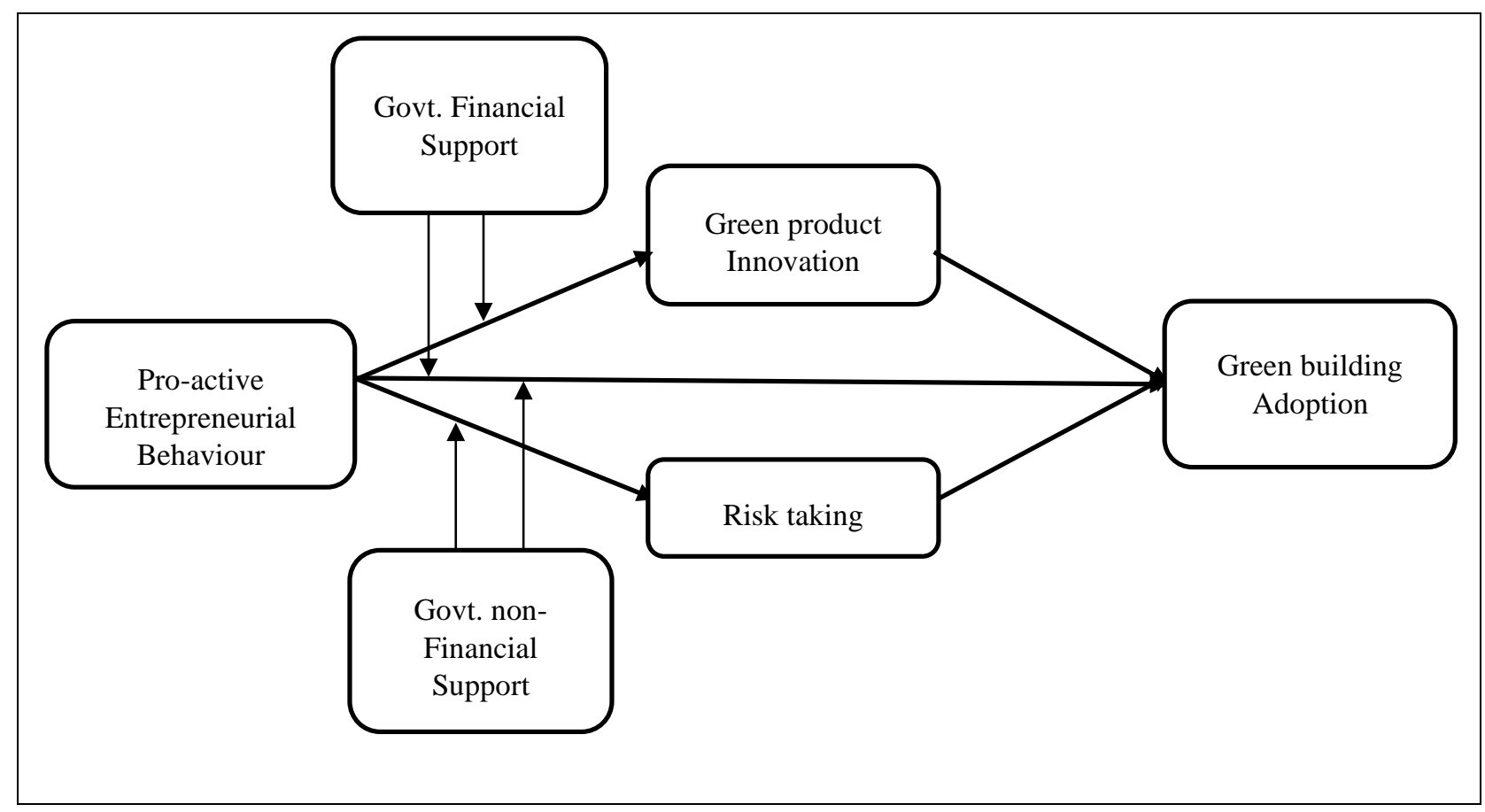

Figure 1. Proposed Conceptual frameworks for Green Building Adoption 


\section{CONCLUSION}

The proposed conceptual model will be beneficial to the Saudi Arabian government and policymakers. Adoption of new green technologies such as 3D house printing, solar panels, wind energy, sun-resistant energy glasses, internet of things in homes, green building materials, 3D structures for saving energy, pollution prevention, waste recycling, and green products would enable the country to protect the environment from air pollution and contemporary Saudi Arabian lifestyle. The conceptual model also suggested that the Saudi Arabian government should be able to provide support to construction firms both financially and non-financially. Non-financial support such as holding workshops, seminars, and training will enhance construction SMEs employees' green building knowledge and capability. In addition, the proposed model is aligned with the Saudi Arabian economic development plan and the 2030 vision.

With the recent Vision 2030 of Saudi Arabia and the economic policy shift from dependency on oil to other different sectors, green housing projects have become one of the flagships. Moreover, Saudi Arabian air pollution is high, partly due to its geographical area that is covered by desert and non-green building construction technology. With the advancement of green building technology around the globe, Saudi construction SMEs can adopt these new norms in housing estate development projects easily. They are known as green building technologies. The examples of green building technologies are 3D house printing, solar panels, wind energy, sun-resistant energy glasses, and internet of things in homes, green building materials, 3D structures for saving energy, pollution anticipation, waste recycling, green products, and also corporate environmental managing practices that promote sustainability. Compared to the traditional building materials, green building technology and built materials are environmentally friendly and advantageous to humans (Akadiri, 2015).

In conclusion, this paper highlighted the factors that should be addressed to promote green building adoption among the SME contractors involved in construction building. Based on relevant literature, proactive entrepreneurial behavior will help improve the construction of SME performance in developing economies if a government regulatory body plays a significant role by finalizing the green building movement and ensuring accountability. The government support for the adoption of green buildings is considered to be one of the fundamental and efficient factors. The Saudi Arabian government can play an essential role in policy setting and implementation, raising public awareness, creation of level playing field, capacity building, and example setting. The government is the most critical stakeholder, and it motivates other stakeholders for green building adoption. Therefore, RBV theory as the underpinning theory is suitable to link all the factors i.e., government support (financial, non-financial), proactive entrepreneurial behaviors, innovation, and risktaking in the context of construction contractors' green-building adoption in Saudi Arabia.

\section{REFERENCES}

Abuzeinab, A., Arif, M., Qadri, M. A., \& Kulonda, D. (2018). Green business models in the construction sector: an analysis of outcomes and benefits. Construction Innovation.

Akadiri, P. O. (2015). Understanding the barriers affecting the selection of sustainable materials in building projects. Journal of Building Engineering, 4, 86-93.

Alnaser, W. E., \& Alnaser, N. W. (2011). The status of renewable energy in the GCC countries. Renewable and sustainable energy reviews, 15(6), 3074-3098.

Alrashed, F., \& Asif, M. (2015). Analysis of critical climate related factors for the application of zero-energy homes in Saudi Arabia. Renewable and sustainable energy reviews, 41, 1395-1403.

Alshuwaikhat, H. M., \& Mohammed, I. (2017). Sustainability matters in national development visions-Evidence from Saudi Arabia's Vision for 2030. Sustainability, 9(3), 408.

Alyami, S. H., Rezgui, Y., \& Kwan, A. (2013). Developing sustainable building assessment scheme for Saudi Arabia: Delphi consultation approach. Renewable and Sustainable Energy Reviews, 27, 43-54.

Alyami, S. H., Rezgui, Y., \& Kwan, A. (2015). The development of sustainable assessment method for Saudi Arabia built environment: weighting system. Sustainability Science, 10(1), 167-178.

Amran, Y. A., Amran, Y. M., Alyousef, R., \& Alabduljabbar, H. (2020). Renewable and sustainable energy production in Saudi Arabia according to Saudi Vision 2030; Current status and future prospects. Journal of Cleaner Production, 247, 119602.

Azar, E., \& Menassa, C. C. (2012). Agent-based modeling of occupants and their impact on energy use in commercial buildings. Journal of Computing in Civil Engineering, 26(4), 506-518.

Bahidrah, S., \& Korkmaz, K. A. (2017). Barriers to the implementation of the 2030 Saudi Visions Sustainable Construction Objectives. Middle East Journal of Entrepreneurship, Leadership \& Sustainable Development, 1(1), 33-42.

Bamgbade, J. A., Kamaruddeen, A. M., Nawi, M. N. M., Yusoff, R. Z., \& Bin, R. A. (2018). Does government support matter? Influence of organizational culture on sustainable construction among Malaysian contractors. International Journal of Construction Management, 18(2), 93-107.

Banani, R., Vahdati, M. M., Shahrestani, M., \& Clements-Croome, D. (2016). The development of building assessment criteria framework for sustainable non-residential buildings in Saudi Arabia. Sustainable Cities and Society, 26, 289-305.

Barclay, D., Higgins, C., \& Thompson, R. (1995). The partial least squares (PLS) approach to casual modeling: personal computer adoption ans use as an Illustration.

Barney, J. (1991). Firm resources and sustained competitive advantage. Journal of management, 17(1), 99-120. 
Beltramello, A., Haie-Fayle, L., \& Pilat, D. (2013). Why new business models matter for green growth.

Brandao-Marques, L., Correa, R., \& Sapriza, H. (2020). Government support, regulation, and risk taking in the banking sector. Journal of Banking \& Finance, 112, 105284.

Buyle, M., Braet, J., \& Audenaert, A. (2013). Life cycle assessment in the construction sector: A review. Renewable and sustainable energy reviews, 26, 379-388.

Calderón, C., James, P., Urquizo, J., \& McLoughlin, A. (2015). A GIS domestic building framework to estimate energy end-use demand in UK sub-city areas. Energy and Buildings, 96, 236-250.

CCPI, 2020, Climate Change Performance Index annual meeting, https://www.climate-change-performance-index.org/

Chang, C. H. (2018). How to enhance green service and green product innovation performance? The roles of inward and outward capabilities. Corporate Social Responsibility and Environmental Management, 25(4), 411-425.

Covin, J. G., \& Slevin, D. P. (1989). Strategic management of small firms in hostile and benign environments. Strategic Management Journal, 10(1), 75-87.

Crawley, D., \& Aho, I. (1999). Building environmental assessment methods: applications and development trends. Building Research \& Information, 27(4-5), 300-308.

Dangelico, R. M., Pujari, D., \& Pontrandolfo, P. (2017). Green product innovation in manufacturing firms: A sustainability-oriented dynamic capability perspective. Business strategy and the Environment, 26(4), 490-506.

Darko, A., \& Chan, A. P. (2016). Critical analysis of green building research trend in construction journals. Habitat International, 57 , 53-63.

Dohaiman, M. S. A. (2017). The impact of stock market and macroeconomic variables on real estate prices dynamics: Evidence from Saudi Arabia. International Journal of Sustainable Real Estate and Construction Economics, 1(1), 3-15.

Fiaz, S., Noor, M. A., \& Aldosri, F. O. (2018). Achieving food security in the Kingdom of Saudi Arabia through innovation: Potential role of agricultural extension. Journal of the Saudi Society of Agricultural Sciences, 17(4), 365-375.

Hagihara, J. (2013). Saudi Arabia's domestic energy situation and policy: focusing on its power sector.

Kelly, G. (2012). Sustainability at home: Policy measures for energy-efficient appliances. Renewable and Sustainable Energy Reviews, 16(9), 6851-6860.

Khan, R. U. (2019). Relationship of HR practices and career path: A perspective of accounting studies. Jinnah Business Review, 7(1), 46-56.

Khan, R. U., \& Ghufran, H. (2018). The mediating role of perceived organizational support between qualitative job insecurity, organizational citizenship behavior and job performance. J Entrepren Organiz Manag, 7(228), 2.

Krejcie, R. V., \& Morgan, D. W. (1970). Determining sample size for research activities. Educational and Psychological Measurement, 30(3), 607-610.

Li, Q., Long, R., Chen, H., Chen, F., \& Cheng, X. (2019). Chinese urban resident willingness to pay for green housing based on doubleentry mental accounting theory. Natural Hazards, 95(1-2), 129-153.

Li, Q., Long, R., Chen, H., Chen, F., \& Wang, J. (2020). Visualized analysis of global green buildings: Development, barriers and future directions. Journal of Cleaner Production, 245, 118775.

Li, S., Jayaraman, V., Paulraj, A., \& Shang, K. C. (2016). Proactive environmental strategies and performance: Role of green supply chain processes and green product design in the Chinese high-tech industry. International Journal of Production Research, 54(7), 2136-2151.

Liu, G., Ko, W. W. J., Ngugi, I., \& Takeda, S. (2017). Proactive entrepreneurial behaviour, market orientation, and innovation outcomes. European Journal of Marketing, 51(12), 1980-2001.

Lumpkin, G. T., \& Dess, G. G. (1996). Clarifying the entrepreneurial orientation construct and linking it to performance. Academy of Management Review, 21(1), 135-172.

Maqsoom, A., Choudhry, R. M., Umer, M., \& Mehmood, T. (2019). Influencing factors indicating time delay in construction projects: Impact of firm size and experience. International Journal of Construction Management, 1-12.

Mitrega, M., Forkmann, S., Zaefarian, G., \& Henneberg, S. C. (2017). Networking capability in supplier relationships and its impact on product innovation and firm performance. International Journal of Operations \& Production Management. p1-63.

Mosly, I. (2015). Barriers to the diffusion and adoption of green buildings in Saudi Arabia. J. Mgmt. \& Sustainability, 5, 104.

Mosly, I., \& Makki, A. A. (2018). Current status and willingness to adopt renewable energy technologies in Saudi Arabia. Sustainability, 10(11), 4269.

Neneh, B. N. (2019). From entrepreneurial alertness to entrepreneurial behavior: The role of trait competitiveness and proactive personality. Personality and Individual Differences, 138, 273-279.

Nguyen, T. A., \& Aiello, M. (2013). Energy intelligent buildings based on user activity: A survey. Energy and buildings, 56, $244-257$.

Ong, H. C., Mahlia, T. M. I., \& Masjuki, H. H. (2011). A review on energy scenario and sustainable energy in Malaysia. Renewable and Sustainable Energy Reviews, 15(1), 639-647.

Ong, T. S., Lee, A. S., Teh, B. H., \& Magsi, H. B. (2019). Environmental innovation, environmental performance and financial performance: Evidence from Malaysian environmental proactive firms. Sustainability, 11(12), 3494.

Quan, Y., Wu, H., Li, S., \& Ying, S. X. (2018). Firm sustainable development and stakeholder engagement: The role of government support. Business Strategy and the Environment, 27(8), 1145-1158. 
Rahardjati, R., Khamidi, M. F., \& Idrus, A. (2011, February). Green building rating system: The need of material resources criteria in green building assessment. In 2nd International Conference on Environmental Science and Technology (ICEST) IEEE.

Rodríguez López, F., \& Fernández Sánchez, G. (2011). Challenges for sustainability assessment by indicators. Leadership and Management in Engineering, 11(4), 321-325.

Ryszko, A. (2016). Proactive environmental strategy, technological eco-innovation and firm performance-Case of poland. Sustainability, 8(2), 156.

Short, S. W., Bocken, N. M., Barlow, C. Y., \& Chertow, M. R. (2014). From refining sugar to growing tomatoes: Industrial ecology and business model evolution. Journal of Industrial Ecology, 18(5), 603-618.

Strauss, K., Parker, S. K., \& O'Shea, D. (2017). When does proactivity have a cost? Motivation at work moderates the effects of proactive work behavior on employee job strain. Journal of Vocational Behavior, 100, 15-26.

Tajeddini, K., \& Mueller, S. L. (2012). Corporate entrepreneurship in Switzerland: evidence from a case study of Swiss watch manufacturers. International Entrepreneurship and Management Journal, 8(3), 355-372.

Thongsri, N., \& Chang, A. K. H. (2019). Interactions among factors influencing product innovation and innovation behaviour: Market orientation, managerial ties, and government support. Sustainability, 11(10), 2793.

Uddin, M. H. (2016). Effect of government share ownership on corporate risk taking: Case of the United Arab Emirates. Research in International Business and Finance, 36, 322-339.

Xie, X., Huo, J., \& Zou, H. (2019). Green process innovation, green product innovation, and corporate financial performance: A content analysis method. Journal of Business Research, 101, 697-706.

Xie, X., Huo, J., \& Zou, H. (2019). Green process innovation, green product innovation, and corporate financial performance: A content analysis method. Journal of Business Research, 101, 697-706.

Yadegaridehkordi, E., Hourmand, M., Nilashi, M., Alsolami, E., Samad, S., Mahmoud, M., ... \& Shuib, L. (2020). Assessment of sustainability indicators for green building manufacturing using fuzzy multi-criteria decision making approach. Journal of Cleaner Production, 277, 122905.

Yamada, M. Vision 2030 and the Birth of Saudi Solar Energy; Middle East Institute: Washington, DC, USA, 2016.

Zhang, J., \& Guan, J. (2018). The time-varying impacts of government incentives on innovation. Technological Forecasting and Social Change, 135, 132-144.

\section{AUTHORS' BIOGRAPHY \& AUTHOR PROFESSIONAL PICTURE}

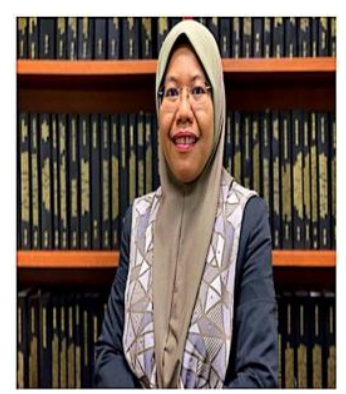

Dr. Norfarah Nordin is a Senior Lecturer at the Graduate School of Business, Universiti Sains Malaysia. Her research has focused on the area of entrepreneurs' behavior and Small-Medium- Enterprise. Her current research focuses on social media usage for business decision-making, business analytics, and entrepreneurship.

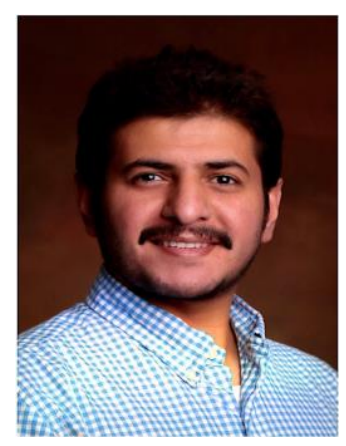

Asem Alkahtani is a PhD student at the Graduate School of Business at Universiti Sains Malaysia. His main research interest concerns green business, with a particular focus on greenconstruction companies. 